\title{
Expression of anti-SRP19 antibody in muscle tissues from patients with autoimmune necrotizing myopathy
}

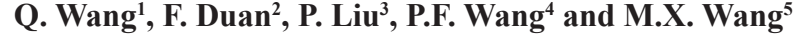 \\ ${ }^{1}$ EmergencyDepartment, \\ General Hospital of Chinese People's Armed Police Forces, Beijing, China \\ ${ }^{2}$ Department of Neurology, Navy General Hospital, Beijing, China \\ ${ }^{3}$ Department of VIP Neurology, Navy General Hospital, Beijing, China \\ ${ }^{4}$ Department of Neurology, Aerospace Center Hospital, \\ Peking University Aerospace Clinical College, Beijing, China \\ ${ }^{5}$ Orthopaedics Department, \\ General Hospital of Chinese People's Armed Police Forces, Beijing, China \\ Corresponding author: M.X. Wang \\ E-mail: wq13910699301@qq.com
}

Genet. Mol. Res. 15 (3): gmr.15038307

Received December 21, 2015

Accepted March 18, 2016

Published August 12, 2016

DOI http://dx.doi.org/10.4238/gmr.15038307

Copyright (C) 2016 The Authors. This is an open-access article distributed under the terms of the Creative Commons Attribution ShareAlike (CC BY-SA) 4.0 License

\begin{abstract}
This study aimed to investigate the role of anti-SRP19 antibody in muscle tissues of patients with autoimmune necrotizing myopathy. Immunohistochemistry staining was used to determine the expression of anti-SRP19 antibodies in muscle tissues of autoimmune necrotizing myopathy patients. Results demonstrated that anti-SRP19 antibody was expressed in $71.4 \%(20 / 28)$ of muscle tissue specimens from patients with autoimmune necrotizing myopathy. Anti-SRP19 antibody expression was mainly localized in cytoplasm of necrotic muscle fibers surrounding the small blood vessels and interstitial cells.
\end{abstract}


There were no significant differences in the age, course of disease, muscle, and creatine kinase levels between patients with positive or negative expression of anti-SRP19 antibodies. The expression levels of anti-SRP19, serum anti-nuclear antibodies, as well as anti-Ro-52, antiSSA, anti-Sm, and anti-Jo-1 antibodies were not significantly different among groups. This study demonstrates that anti-SRP19 antibody is highly expressed in muscle tissues of patients with autoimmune necrotizing myopathy, and suggests that this protein may be involved in the origin and progression of the disease.

Key words: Immune necrotizing myopathy; Immunohistochemistry; Signal recognizing particle; $\operatorname{IgG}$

\section{INTRODUCTION}

Necrotizing myopathy (NM) is a form of idiopathic inflammatory myopathy, where the main pathologic feature is the regeneration and necrosis of muscle fibers with or without infiltration of inflammatory cells. NM differs in pathology from other forms of idiopathic inflammatory myopathies such as polymyositis (PM), dermatomyositis (DM), inclusion body myositis, and non-specific myositis (Hoogendijk et al., 2004; Suzuki et al., 2015). NM is always associated with tumors, viral infections, the presence of toxic drugs, and muscle or connective tissue diseases. One form of NM is autoimmune necrotizing myopathy (Kassardjian et al., 2015; Tavares et al., 2015). Miller et al. (2002) described a resistant signal recognition particle (SRP) antibody in the sera of 7 patients. The relationship between SRP expression and the pathogenic mechanism of autoimmune necrotizing myopathy has become a major focus of recent research. Some scholars have even suggested that SRP can be regarded as a feature of NM (Hengstman et al., 2006). NM is characterized by acute onset and high morbidity, but can be cured in its early stages (Basnayake et al., 2015; Klein et al., 2015). Some related research in the past has only focused on the expression of SRP19 antibody in patients' sera. However, the expression of SRP19 antibodies in the skeletal muscle tissues and its association with NM is unknown.

\section{MATERIAL AND METHODS}

This study was approved by the local research ethics boards and written informed consents were obtained from all participants prior to enrollment into the study. We recruited 28 patients from our hospital between January and October 2008. Patients were presented with typically diffuse and flaky pathologic myofiber necrosis with no obvious infiltration of inflammatory cells. They complained of muscle weakness and pain, and showed elevated serum creatinine. In addition, electromyography (EMG) revealed myogenic abnormalities. Therefore, these patients were treated with glucocorticoid and immuno-suppressive agents. We screened the patients for drugs and other secondary factors via enzyme-histochemical and immunohistochemical studies. Furthermore, patients with common types of muscular dystrophy and congenital myopathy were also excluded from the study. Disease diagnosis was performed according to the IIM classification diagnostic criteria of autoimmune necrotizing

Genetics and Molecular Research 15 (3): gmr.15038307 
myopathy by Europe and the United States Muscle Research Group in 2004 (Hoogendijk et al., 2004). Confirmation of autoimmune necrotizing myopathy required the following conditions to be satisfied: 1) The age of onset above 18 years old, symmetrical weakness of limb girdle muscles and anterior neck flexors, disease progression from weeks-to-months, with or without dysphagia or respiratory muscle involvement; 2) signs of necrosis, phagocytosis, regeneration, perifascicular atrophy, and inflammatory exudate (often perivascular), as evidenced by muscle biopsies; 3) elevated serum creatinine; and 4) short, small, polyphasic motor units, fibrillations, positive sharp waves, insertional irritability, and high-frequency repetitive discharges in EMG recordings. DM was differentiated from PM by the presence of typical dermatologic features.

\section{Clinical procedures}

Relevant clinical data such as age, gender, duration of disease, form of onset, clinical symptoms, family and personal histories, clinical signs, serum creatinine level, immunologic indices, electromyogram and muscle pathologic biopsy, and the effect of hormone and immune inhibition treatment were collected from 28 patients with autoimmune necrotizing myopathy.

Main parts of the quadriceps and bicep muscle tissues were biopsied and immediately frozen in liquid nitrogen. Frozen section examinations were performed the next day. Tissue specimens were stained using HE, MGT, ORO, NADH, SDH, ACP, PAS, NSE, ATPase, dystroglycan, sarcoglycan, dystrophin, dysferlin, and MHC-1. Morphologic changes were observed and reported by an experienced muscle pathologist.

\section{Immunohistochemistry}

To block endogenous peroxidase activity, pathologic sections were incubated in 3\% $\mathrm{H}_{2} \mathrm{O}_{2}$ at $37^{\circ} \mathrm{C}$ for $10 \mathrm{~min}$, and washed three times in PBS for $5 \mathrm{~min}$. Diluted primary antibody was added [the first antibody was anti-SRP19 antibody (1:125)], and incubated at $37^{\circ} \mathrm{C}$ for $60 \mathrm{~min}$. Tissues were then washed three times in PBS for $5 \mathrm{~min}$. To block non-specific binding, goat serum was added to tissues, and incubated at $37^{\circ} \mathrm{C}$ for $20 \mathrm{~min}$. Tissues were then incubated at $37^{\circ} \mathrm{C}$ for 20 min with two drops of the second-antibody (polymer enhancer), and were washed three times in PBS for $5 \mathrm{~min}$. The secondary antibody, reagent B, was then added (horseradish enzyme marked reagents: goat anti-rat/rabbit polymer), followed by 30 min incubation at $37^{\circ} \mathrm{C}$. Tissues were washed in PBS, and fresh DAB chromogenic liquid was added for 2-3 min at room temperature. Reaction time was controlled according to the degree of coloration. The specimens were washed, re-dyed, dehydrated, and sealed. The sections were viewed under a microscope; necrotic muscular fibrocytes were stained with anti-SRP19 antibodies. According to the staining results, the specimens were divided into positive and negative groups. In the negative group, the cytoplasm was unstained. On the other hand, the positive group showed flaxen, yellow, or brown staining in the cytoplasm.

\section{Antibodies}

The rabbit anti-SRP19 polyclonal antibody (ab50932, $100 \mu \mathrm{g}$; Abcam Company, Universal two-step immunohistochemistry detection kit, PV-9000; ZSGB Biological Products Company) was used in immunohistochemical experiments. The antibody agent A included 
in the kit is a polymer enhancer (ready-to-use), while agent B is an enzyme-marked anti-rat/ rabbit polymer (ready-to-use). The chromogenic agent DAB was used for visualization of tissue staining (Beijing ZSGB Biological Products Company).

\section{Statistics}

Statistical analysis was performed using the SPSS17.0 statistical software. Measured data are reported as means \pm standard deviation. The count data are reported as frequencies and percentages. Data were evaluated by the Student $t$-tests and $\mathrm{P}<0.05$ was considered statistically significant.

\section{RESULTS}

We enrolled a total of 14 males and 14 females into the study. The age of onset ranged between 18-67 years, and the mean age was $42.39 \pm 15.26$ years. The peak age groups were between 51 and 60 years of age, and between 31 and 40 years of age (32.1 and 21.4\%, respectively). In the 51-60 year group, 8 patients were identified, in which the male:female ratio was $8: 1$; males were more vulnerable to the disease, but no gender advantage was demonstrated $(\mathrm{P}=0.556)$. EMG recordings showed myogenic abnormalities in all patients.

The pathologic specimens of 28 patients were stained with anti-SRP19 antibody, in which 20 cases were positive [20/28 (71.4\%)], and 8 cases were negative [8/28 (28.6\%)] (Table 1).

Furthermore, immunohistochemical analysis revealed that anti-SRP19 antibodies were mainly expressed in the myofiber cytoplasm (Figure 1), around the small blood vessels, and in the stroma (Figure 2). Anti-SRP19 antibody was also expressed in parts of non-necrotic tissues.

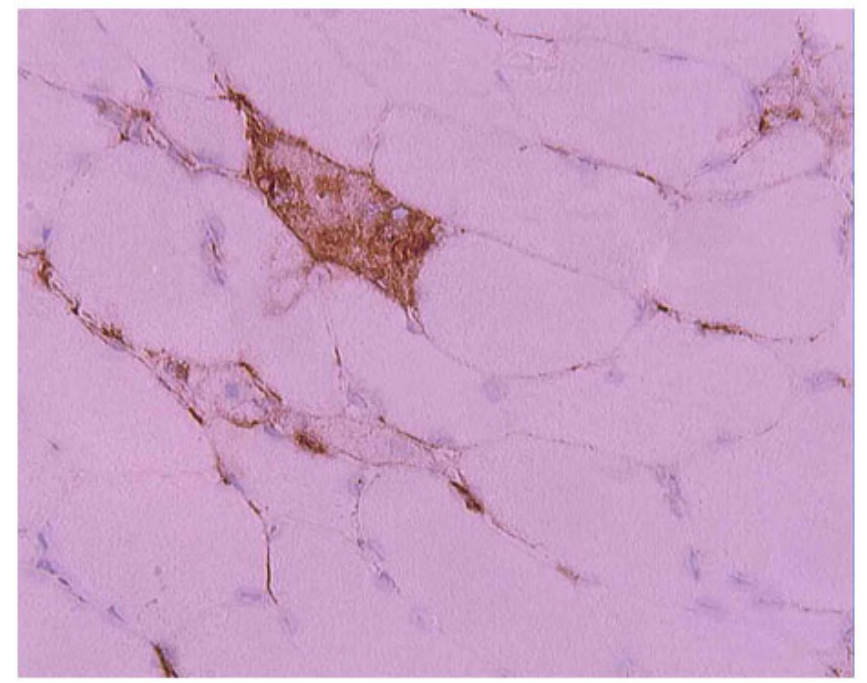

Figure 1. Immunohistochemical staining of anti-SRP19 antibody in necrotic myofiber. Brown color denotes positive staining; image captured at $200 \mathrm{X}$ magnification.

Genetics and Molecular Research 15 (3): gmr.15038307 


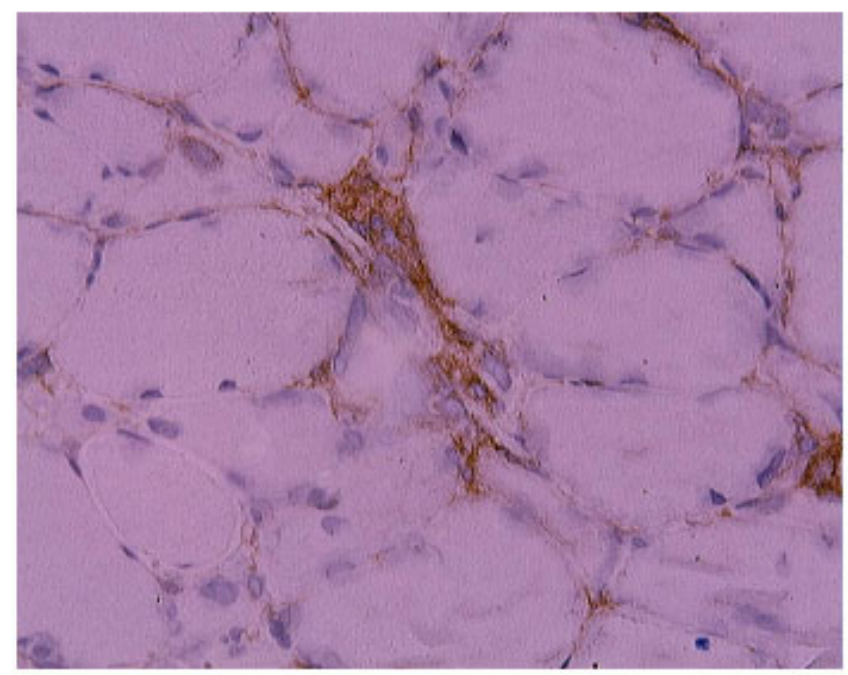

Figure 2. Immunohistochemical staining of anti-SRP19 antibody in inflammatory cell leakage from muscular fibers. Brown color denotes positive staining; image captured at 200X magnification.

Table 1. Changes in enzymes and muscle strength in patients with necrotizing myopathy before and after treatment.

\begin{tabular}{l|c|c|c|c}
\hline Index & Case number & Before & After & P value \\
\hline CK & 28 & $6329.86 \pm 5351.78$ & $1287.15 \pm 1042.12$ & $0.000^{* *}$ \\
\hline Muscle tension & 28 & $3.14 \pm 1.06$ & $3.16 \pm 1.14$ & 0.823 \\
\hline
\end{tabular}

A paired $t$-test was used in analyzing data before and after treatment. $* * \mathrm{P} \leq 0.001$ is statistically significant.

In accordance with the results of anti-SRP19 antibody staining (positive or negative), patients were divided into two groups for analysis of the related clinical data. Table 2 demonstrates the relationship between anti-SRP19 antibody expression and patient gender, age, course of the disease, tension, and creatine kinase (Table 2). In 28 patients, $6(21.4 \%)$ were positive for ENA antibodies, including antinuclear $(\mathrm{N}=5)$, anti-Ro-52 $(\mathrm{N}=2)$, anti-SSA $(\mathrm{N}=$ $1)$, anti-SSm $(\mathrm{N}=1)$, and anti-Jo-1 antibodies $(\mathrm{N}=1) ; 5$ patients $[5 / 28(17.9 \%)]$ had multiple positive antibody titers. Statistical analysis revealed that there was no significant relationship between the expression of anti-SRP19 antibodies and serum anti-nuclear antibodies, antiRo-52 antibodies, anti-SSA antibodies, anti-SSm antibodies, oranti-Jo-1 antibodies (Table 3).

Table 2. Analysis of clinical data between anti-SRP19 antibody positive and negative groups.

\begin{tabular}{|c|c|c|c|}
\hline & \multicolumn{2}{|c|}{ Anti-SRP19 antibody } & \multirow[t]{2}{*}{$P$ value } \\
\hline & Positive $(\mathrm{N}=20)$ & Negative $(\mathrm{N}=8)$ & \\
\hline Gender $(\mathrm{M} / \mathrm{F})$ & $11 / 9$ & $3 / 5$ & \\
\hline Age & $44.75 \pm 14.38$ & $36.50 \pm 16.78$ & 0.202 \\
\hline Duration** & $13.85 \pm 21.48$ & $13.75 \pm 17.02$ & 0.939 \\
\hline Tension & $3.25 \pm 0.95$ & $2.88 \pm 1.33$ & 0.711 \\
\hline Creatine kinase* & $4795.8 \pm 3413.97$ & $9770.43 \pm 7923.02$ & 0.109 \\
\hline
\end{tabular}

**Abnormal distribution, analyzed by the Mann-Whitney test; *unequal variances. P $>0.05$ was statistically significant.

Genetics and Molecular Research 15 (3): gmr.15038307 
Table 3. ENA antibody spectrum analysis between anti-SRP19 antibody positive and negative patients.

\begin{tabular}{l|c|c|c}
\hline \multirow{2}{*}{ ENA antibody spectrum } & \multicolumn{2}{|c|}{ Anti-SRP19 antibody } & \multirow{2}{*}{ P value } \\
\cline { 2 - 3 } & Positive $(\mathrm{N}=20)$ & Negative $(\mathrm{N}=8)$ & 0.281 \\
\hline Anti-nuclear antibody $(+/, \%)$ & $5 / 15,25 \%$ & $0 / 8,0 \%$ & 1.000 \\
\hline Anti-Ro-52 antibody $(+/, \%)$ & $2 / 18,10 \%$ & $0 / 8,0 \%$ & 0.497 \\
\hline Anti-SSA antibody $(+/, \%)$ & $1 / 19,5 \%$ & $1 / 7,12.5 \%$ & 1.000 \\
\hline Anti-SSm antibody $(+/, \%)$ & $1 / 19,5 \%$ & $0 / 8,0 \%$ & 1.000 \\
\hline Anti-Jo-1antibody $(+/-, \%)$ & $1 / 19,5 \%$ & $0 / 8,0 \%$ & \\
\hline
\end{tabular}

Fisher test, $\mathrm{P}>0.05$ was statistically significant.

\section{DISCUSSION}

NM is pathologically characterized by degenerative necrosis without inflammatory cell infiltration. According to the underlying pathogenesis, NM can be divided into secondary and immune types. The former type results from a variety of causes, such as malignant tumors, poisoning, and drugs. However, the causes of the latter type, otherwise known as autoimmune necrotizing myopathy, remain unclear (Bergua et al., 2016). Related studies of immune and necrotic myopathy are rare (Basharat and Christopher-Stine, 2015). We have reported that C5b-9 deposits are present in necrotic myofibers and small blood vessels of autoimmune necrotizing myopathy patients (Cong et al., 2014). In recent years, some scholars have reported the presence of anti-SRP antibody in the sera of patients with necrotizing myopathy, which may be beneficial for studying the pathogenesis of autoimmune necrotizing myopathy, and may lead to potential therapies (Apiwattanakul et al., 2015).

As one of the myositis specific autoantibodies, SPR can be detected through antiSRP54, 72, 19 subunit antibodies and anti-7sl RNA (Satoh et al., 2005; Valiyil et al., 2010). Currently, expression of serum SRP is extensively researched in both domestic and international studies (Benveniste et al., 2011; Fernandez et al., 2013; Hanisch et al., 2013; Wang et al., 2014). It has been demonstrated that serum anti-SRP antibody is closely associated with autoimmune necrotizing myopathy (Picard et al., 2016).

However, the presence or absence of anti-SRP antibodies in muscle tissues and their influence on the pathogenesis of necrotizing myositis has not been reported. The purpose of this study was to observe the SRP19 antibody expression in muscle tissues to confirm if it is involved in cell necrosis, and whether it plays a role in the pathogenesis of SRP-related autoimmune necrotizing myopathy.

It has been reported that the average age of onset in SRP-correlated autoimmune necrotizing myopathy is approximately 50 years old (Carstens and Schmidt, 2014), which is in agreement with results from our present study, where peak onset age was found to be between 51-60 years of age.

Results from studies investigating the positive rate of anti-SRP antibody in the serum of patients with idiopathic inflammatory myopathies have been inconsistent. It is generally believed to be $4-6 \%$ (Dimitri et al., 2007), while the positive rate in PM is 11.9\% (Kao et al., 2004). We found that the positive rate of anti-SRP19 antibodies was $71.4 \%$ in myofibers of autoimmune necrotizing myopathy patients. However, the positive rate of anti-SRP antibody was low in the serum of IIM patients due to either low incidence or limited serologic samples. It is possible that the positive rate may be higher in biopsy samples of IIM patients. We found that anti-SRP antibody was expressed mainly in the cytoplasm of necrotic myofibers, the stroma cells, and the surrounding small blood vessels. Anti-SRP antibody was also expressed

Genetics and Molecular Research 15 (3): gmr.15038307 
in parts of non-necrotic myofibers, suggesting that myofibers were directly attacked by antiSRP19 antibodies, which leads to necrosis. Due to limiting sample conditions, we failed to detect SRP19 antibody expression in both serum and myofibers simultaneously.

We also found that anti-SRP19 antibody expression in muscle tissue of autoimmune NM patients has no apparent association with patient gender, age, duration, tension, creatine kinase, and other myositis-related antibodies. Benveniste et al. (2011) quantitatively measured the level of anti-SRP antibodies in 8 cases of anti-SRP antibody-positive patients before and after glucocorticoid and immunosuppressive therapy, and found that serum CK and anti-SRP antibody concentrations decreased with improved symptoms before and after treatments (Stone et al., 2007; Mohassel and Mammen, 2013). Recent studies have confirmed that improvement of symptoms and remission of necrotizing myopathy is associated with returning of anti-SRP antibody to normal levels. This suggests that SRP is an independent risk factor for autoimmune necrotizing myopathy, and that it could play an important role in the development and outcome of this disease.

As compared with IIM patients, administration of adrenal cortical steroids alone in NM patients is not as effective. When combined with immunosuppressants, we can achieve a relatively satisfactory clinical effect. We found that with combination adrenal cortical steroids and immunosuppressive therapy, the level of serum creatine kinase is decreased, but improvements in muscular strength of patients are minimal. A rapid decline in serum creatine kinase was shown following therapy, which suggests that the immunosuppressive therapy could mitigate disease progression and protect dying myocytes from necrosis (Ramanathan et al., 2015). The lack of improvements in muscle strength following treatment could be attributed to the fact that necrosis is the end stage of cell cycle, and therefore muscle cell regenerative ability is poor. Further studies on the pathogenesis of anti-SRP antibody-related autoimmune necrotic myopathy could lay the foundation for the development of more effective treatments.

\section{Conflicts of interests}

The authors declare no conflict of interest.

\section{ACKNOWLEDGMENTS}

This study was not supported by any grants.

\section{REFERENCES}

Apiwattanakul M, Milone M, Pittock SJ, Kryzer TJ, et al. (2015). SRP-IgG detected incidentally associates with autoimmune myopathy. Muscle Nerve $\cdots$ : 12; Epub ahead of print.

Basharat P and Christopher-Stine L (2015). Immune-mediated necrotizingmyopathy: update on diagnosis and management. Curr. Rheumatol. Rep. 17: 72. http://dx.doi.org/10.1007/s11926-015-0548-6

Basnayake SK, Blumbergs P, Tan JA, Roberts-Thompson PJ, et al. (2015). Inflammatory myopathy with anti-SRP antibodies: case series of a South Australian cohort. Clin. Rheumatol. 34: 603-608. http://dx.doi.org/10.1007/s10067$\underline{014-2512-7}$

Benveniste O, Drouot L, Jouen F, Charuel JL, et al. (2011). Correlation of anti-signal recognition particle autoantibody levels with creatine kinase activity in patients with necrotizing myopathy. Arthritis Rheum. 63: 1961-1971. http:// dx.doi.org/10.1002/art.30344

Bergua C, Chiavelli H, Simon JP, Boyer O, et al. (2016). Immune-mediated necrotizing myopathy. Z. Rheumatol. 75: 151156; Epub ahead of print. http://dx.doi.org/10.1007/s00393-015-0029-3

Genetics and Molecular Research 15 (3): gmr.15038307 
Carstens PO and Schmidt J (2014). Diagnosis, pathogenesis and treatment of myositis: recent advances. Clin. Exp. Immunol. 175: 349-358. http://dx.doi.org/10.1111/cei.12194

Cong L, Pu CQ, Shi Q, Wang Q, et al. (2014). Complement membrane attack complex is related with immune-mediated necrotizing myopathy. Int. J. Clin. Exp. Pathol. 7: 4143-4149.

Dimitri D, Andre C, Roucoules J, Hosseini H, et al. (2007). Myopathy associated with anti-signal recognition peptide antibodies: clinical heterogeneity contrasts with stereotyped histopathology. Muscle Nerve 35: 389-395. http:// dx.doi.org/10.1002/mus.20693

Fernandez C, Bardin N, De Paula AM, Salort-Campana E, et al. (2013). Correlation of clinicoserologic and pathologic classifications of inflammatory myopathies: study of 178 cases and guidelines for diagnosis. Medicine (Baltimore) 92: 15-24. http://dx.doi.org/10.1097/MD.0b013e31827ebba1

Hanisch F, Müller T, Stoltenburg G and Zierz S (2013). Unusual manifestations in two cases of necrotizing myopathy associated with SRP antibodies. Rheumatol. Int. 33: 1371-1372. http://dx.doi.org/10.1007/s00296-011-2311-2

Hengstman GJ, ter Laak HJ, Vree Egberts WT, Lundberg IE, et al. (2006). Anti-signal recognition particle autoantibodies: marker of a necrotising myopathy. Ann. Rheum. Dis. 65: 1635-1638. http://dx.doi.org/10.1136/ard.2006.052191

Hoogendijk JE, Amato AA, Lecky BR, Choy EH, et al. (2004). 119th ENMC international workshop: trial design in adult idiopathic inflammatory myopathies, with the exception of inclusion body myositis, 10-12 October 2003, Naarden, The Netherlands. Neuromuscul. Disord. 14: 337-345. http://dx.doi.org/10.1016/j.nmd.2004.02.006

Kao AH, Lacomis D, Lucas M, Fertig N, et al. (2004). Anti-signal recognition particle autoantibody in patients with and patients without idiopathic inflammatory myopathy. Arthritis Rheum. 50: 209-215. http://dx.doi.org/10.1002/ art.11484

Kassardjian CD, Lennon VA, Alfugham NB, Mahler M, et al. (2015). Clinical features and treatment outcomes of necrotizing autoimmune myopathy. JAMA Neurol. 72: 996-1003. http://dx.doi.org/10.1001/jamaneurol.2015.1207

Klein M, Mann H, Pleštilová L, Zámečník J, et al. (2015). Increasing incidence of immune-mediated necrotizing myopathy: single-centre experience. Rheumatology (Oxford) 54: 2010-2014. http://dx.doi.org/10.1093/rheumatology/kev229

Miller T, Al-Lozi MT, Lopate G and Pestronk A (2002). Myopathy with antibodies to the signal recognition particle: clinical and pathological features. J. Neurol. Neurosurg. Psychiatry 73: 420-428. http://dx.doi.org/10.1136/jnnp.73.4.420

Mohassel P and Mammen AL (2013). Statin-associated autoimmune myopathy and anti-HMGCR autoantibodies. Muscle Nerve 48: 477-483. http://dx.doi.org/10.1002/mus.23854

Picard C, Vincent T, Lega JC, Hue S, et al. (2016). Heterogeneous clinical spectrum of anti-SRP myositis and importance of the methods of detection of anti-SRP autoantibodies: a multicentric study. Immunol. Res. 64: 677-686; Epub ahead of print. http://dx.doi.org/10.1007/s12026-015-8774-6

Ramanathan S, Langguth D, Hardy TA, Garg N, et al. (2015). Clinical course and treatment of anti-HMGCR antibodyassociated necrotizing autoimmune myopathy. Neurol. Neuroimmunol. Neuroinflamm. 2: e96. http://dx.doi. org/10.1212/NXI.0000000000000096

Suzuki S, Nishikawa A, Kuwana M, Nishimura H, et al. (2015). Inflammatory myopathy with anti-signal recognition particle antibodies: case series of 100 patients. Orphanet J. Rare Dis. 10: 61. http://dx.doi.org/10.1186/s13023-015$\underline{0277-y}$

Satoh T, Okano T, Matsui T, Watabe H, et al. (2005). Novel autoantibodies against 7SL RNA in patients with polymyositis/ dermatomyositis. J. Rheumatol. 32: 1727-1733.

Stone KB, Oddis CV, Fertig N, Katsumata Y, et al. (2007). Anti-Jo-1 antibody levels correlate with disease activity in idiopathic inflammatory myopathy. Arthritis Rheum. 56: 3125-3131. http://dx.doi.org/10.1002/art.22865

Tavares NAC, Santos MMS, Moura R, Araújo J, et al. (2015). Association of TNF- $\alpha$, CTLA4, and PTPN22 polymorphisms with type 1 diabetes and other autoimmune diseases in Brazil. Genet. Mol. Res. 14: 18936-18944. http://dx.doi. org/10.4238/2015.December.28.42

Valiyil R, Casciola-Rosen L, Hong G, Mammen A, et al. (2010). Rituximab therapy for myopathy associated with antisignal recognition particle antibodies: a case series. Arthritis Care Res. (Hoboken) 62: 1328-1334. http://dx.doi. org/10.1002/acr.20219

Wang L, Liu L, Hao H, Gao F, et al. (2014). Myopathy with anti-signal recognition particle antibodies: clinical and histopathological features in Chinese patients. Neuromuscul. Disord. 24: 335-341. http://dx.doi.org/10.1016/j. nmd.2014.01.002

Genetics and Molecular Research 15 (3): gmr.15038307 